\title{
A PRELIMINARY STUDY: APPLYING PROBLEM-POSING LEARNING MODELS ON ALGORITHM AND FLOWCHART MATERIALS IN BASIC PROGRAMMING CLASS
}

\author{
Aulia Akhrian Syahidi ${ }^{1}$, Herman Tolle ${ }^{2}$, Ahmad Afif Supianto ${ }^{3}$, Tsukasa Hirashima ${ }^{4}$ \\ ${ }^{I}$ Chair of Interactive Media, Game, and Mobile Technologies Research Group, \\ Politeknik Negeri Banjarmasin, Indonesia \\ ${ }^{2}$ Head of Media, Game, and Mobile Technologies Research Group, Brawijaya University, Indonesia \\ ${ }^{3}$ Head of Technology-Enhanced Learning Research Group, Brawijaya University, Indonesia \\ ${ }^{4}$ Head of Learning Engineering Laboratory, Hiroshima University, Japan \\ Email: aakhriansyahidi@poliban.ac.id
}

\begin{tabular}{|l|l}
\hline $\begin{array}{l}\text { Article History } \\
\text { Received: 27-04-2020 }\end{array}$ & $\begin{array}{l}\text { Abstrak } \\
\text { Accepted: 14-05-2020 } \\
\text { Published: 20-05-2020 propose the applying of the problem-posing learning model to find out the } \\
\text { activities and student learning outcomes in learning algorithm and flowchart } \\
\text { material in the basic programming class. This research is a preliminary study } \\
\text { that will be used to develop applications/systems/interactive media/games that } \\
\text { will support the operation of the problem-posing learning model automatically } \\
\text { in the upcoming basic programming class. The classroom action research } \\
\text { method was used with the implementation of two cycles involving 38 students } \\
\text { in the first semester of vocational high school. The process of applying the } \\
\text { problem-posing learning model uses the pre-solution posing type, which } \\
\text { requires that each student make a question of the situation that is held, where } \\
\text { students are expected to be able to make questions related to questions } \\
\text { research; programming } \\
\text { learning, student } \\
\text { activities, learning } \\
\text { outcomes }\end{array}$ \\
\hline $\begin{array}{l}\text { previously made by the teacher, then exchange the questions to other students } \\
\text { to solve them. The flow of making and solving questions is that students make } \\
\text { the main case which then completes it in the form of algorithmic answers and } \\
\text { also a flowchart assisted by the Raptor application. By applying the problem- } \\
\text { posing learning model, it can be concluded that in cycle 1 and cycle 2 the } \\
\text { achievement of learning activities and outcomes tends to be good. The success } \\
\text { of this research can provide perspective and guidance for developing basic } \\
\text { programming applications/systems/interactive media/games that will instill the } \\
\text { problem-posing learning model in the interaction flow and can introduce } \\
\text { students early on the problem-posing process. }\end{array}$
\end{tabular}




\section{INTRODUCTION}

Basic programming is a subject that must be studied by students in vocational high schools, is part $\mathrm{C} 2$ as the basis of the expertise program, taught only to tenth grade in the first and second semester with an allocation of 3 hours of study x 45 minutes per week for a total of 108 hours (KEMDIKBUD RI, 2018). Basic programming functions as a means of basic understanding in programming languages, a basis for other subjects, training students' logic and creativity (Syahidi, Asyikin, \& Asy'ari, 2018). According to Likmalatri (2018), basic programming is a subject that teaches and trains students to understand and apply programming languages whose functions can also be applied in other programming languages.

Basic programming is one of the subjects that is difficult for students to understand, this has been conveyed by several studies. Even though this subject is very useful for students who want to master the programming language and its application in making projects. According to Soloway \& Spohrer (1989) states that to be a reliable expert programmer, a minimum of 10 years of training is required. Some studies that state that basic programming subjects are very difficult and have their obstacles in the implementation of the learning process, namely from Malliarakis, Satratzemi, \& Xinogalos (2014); Yang, Hwang, Yang, \& Hwang (2015); Kunkle \& Allen (2016); Dwinanto (2017); Rozali \& Zaid (2017); Topalli \& Cagiltay (2018). From these various constraints, some researchers have proposed good solutions in the form of the application of models, approaches, strategies and learning innovations. Including proposing the development of systems, applications, and media by utilizing computer intelligence technology to help minimize these problems. However, the same problems were still encountered due to differences in the subject or area of the research conducted.

From the statements that have been submitted by the previous researchers, we directly prove the condition by conducting interviews and observations to several schools. We want to know that studying the material in basic programming is indeed not easy and has problems. Our findings are from the results of interviews with basic programming teachers, that there are obstacles encountered in the basic programming learning process. The obstacles faced are learning tends to still be centered on the teacher, the level of understanding and absorption of students is low, learning motivation is low, learning models are not applied, do not use learning media, low student activities, resulting in low student learning outcomes. Based on observations by spreading questionnaires to students, that basic programming learning is difficult, students do not like it, they on average propose learning media, and the application of learning models in the implementation of basic programming learning.

Research that has proposed the application of a learning model on basic programming subjects is carried out by Daungcharone, Panjaburee, \& Thongkoo (2017) which applies the student-centered learning model in an educational game scenario for programming learning in $\mathrm{C}$ language introductory material. Research by Hong \& Chu (2017) who applies computational problem-solving learning models in game-based learning scenarios for programming learning on a variable, if-else, and while loops. Then from Kiss \& Arki (2017) applying game-based learning models in game-based learning scenarios for programming learning in language introductory material C. Research from Stigall, Sharma, \& Member (2017) which applies constructivism learning models in game-based learning scenarios based on virtual reality for programming learning in object-oriented programming and binary search material. Research by Debabi \& Champagnat (2017) applies pedagogical teaching and learning models in serious game elements for programming learning in algorithmic material. Next is the research from Hsu \& Lin (2017) who applied the problem-based learning model in the element of digital game-based learning in computer programming learning.

We also adopted a study by Hirashima, Yokoyama, Okamoto, \& Takeuchi (2008) who developed an interactive learning environment system called Monsakun, embracing the interaction of problemposing learning models for elementary school students. In the study of Supianto, Hayashi, \& Hirashima (2016) the application of problem-posing to the system of Monsakun can be described as a series of the 
composition of sentence cards in three available cards slots. Students can submit problems by arranging the sentences given and the session requires students to continue to cause problems until they can cause problems to meet the requirements. As a result, students make many compositions of sentence cards in three available card slots. Furthermore, the Monsakun system of communication continues to experience very dynamic development, this can be seen in the results of research from Supianto, Hayashi, \& Hirashima (2017) where the Monsakun system of communication is used as a means to analyze and evaluate student attitudes, students' mindsets, and even systems that understand what thought of students. The development of the MONSAKUN system by Supianto \& Hafis (2018) utilizes data logs to explore patterns and data relationships to understand learning experiences and identify the status of student traps in the learning process.

Research that proposes the application of problem-posing learning models to basic programming subjects, conducted by Kunimune \& Niimura (2014) which develops an educational game system that applies elements of problem-posing learning models to learning programming in basic $\mathrm{C}$ programming language materials, but the obstacle faced is that students tend to be confused and do not understand the implementation of the problem-posing learning model so that in the research suggestions section they recommend conducting an initial introduction or preliminary study to introduce the model.

Based on this background, the field of research we undertake is a preliminary study that proposes the application of the problem-posing learning model with the type of pre-solution posing that is applied in basic programming classes. We aim to find out the percentage of activities, learning outcomes, and as an effort to introduce the implementation of the problem-posing learning model to students. This research contributes as a preliminary study to develop applications/systems/interactive media/games automatically based on problem-posing learning models to improve learning in basic programming classes in the future and provide solutions so that learning basic programming tends to be easier. What distinguishes it from previous research is that the research we are proposing now is an initial step in developing a product in a scientific and directed manner. The need for this preliminary study has been submitted by Kunimune et al. (2014) which is one of the objectives to introduce the proposed model to potential end-users of the product to be developed.

\section{RESEARCH METHODOLOGY}

\section{Types of Research}

This study proposes the use of a type of classroom action research. The purpose of this classroom action research is to improve practice in learning. According to Rapoport (1970) in Hopkins (2008) states that action research is carried out based on concerns about the practical problems directly faced by people, in which this action research can contribute to overcoming the problem by referring to the agreed framework together.

The theory from Kemmis (1983) in Hopkins (2008) explains that action research is a reflective investigation with the main actors are learners who are advised to apply collaboratively, where in the world of education it has its utility as a process in developing school curricula, professional development, programs in improving the quality of schools, system planning, and references in making policies.

Action research from Mills (2003) in Hopkins (2008) states that teachers or researchers conduct systematic investigations aimed at exploring information relating to school processes in operation, teacher techniques in teaching, and ways students learn. According to Arikunto (2014) in the implementation of classroom action research there are four stages need to be done namely 1) Planning; 2) Actions; 3) Observations; 4) Reflection. A diagram of the stages of a classroom action research can be seen in Figure 1. 


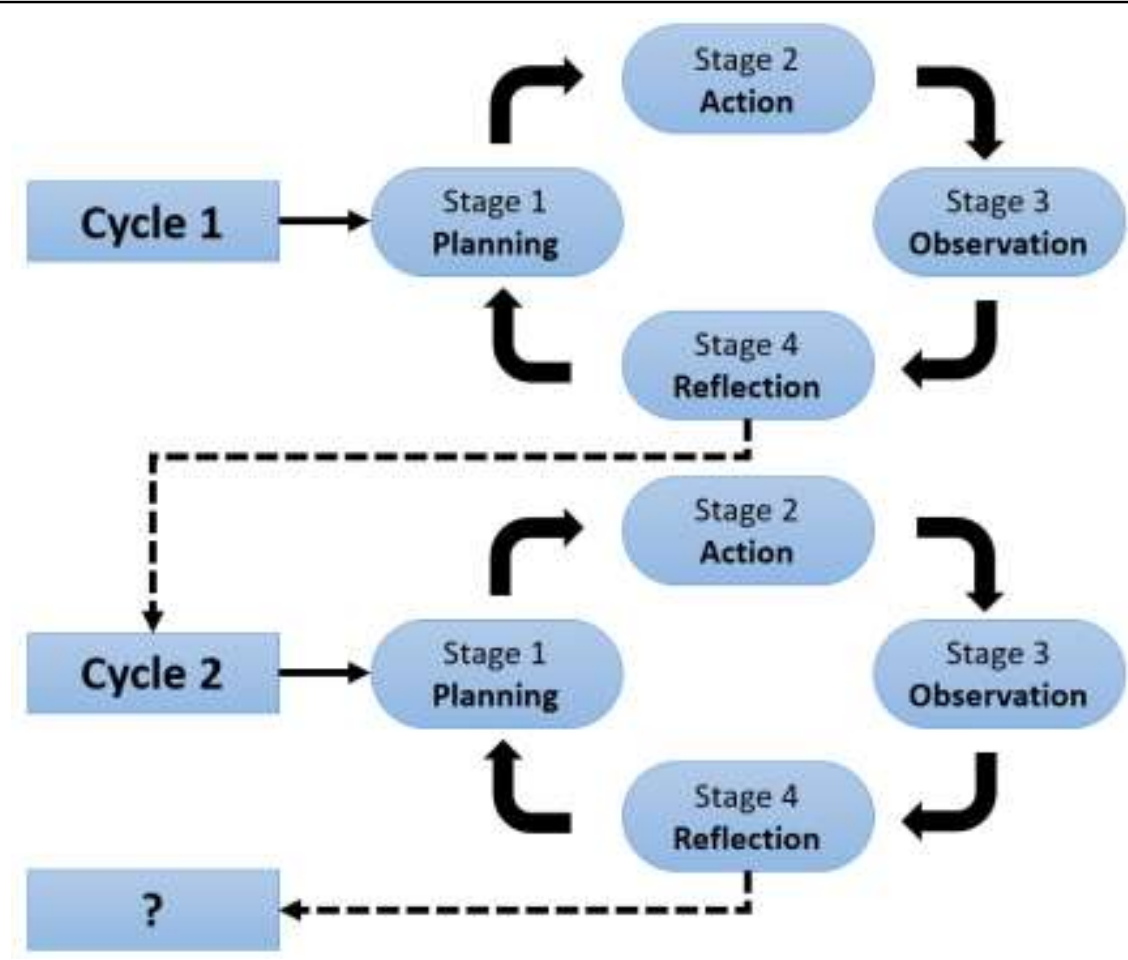

Figure 1. Classroom Action Research Methodology

Based on Figure 1, according to Arikunto (2014) mention that if finished with the second cycle and not satisfied, can continue with the third cycle, the method and stages are the same as the previous cycle, suggesting a minimum of two cycles. If the results of the second cycle are different from the first cycle, it is clear that the researcher must carry out the third cycle and then until strong conclusions are obtained. If the result of the second cycle is the same as the first cycle, that means there is stabilization. Based on this theory, researchers conduct classroom action research consisting of at least two cycles.

The processes in the implementation of each stage in cycle 1 were adapted from the research of Syahidi et al. (2018), namely as follows: Compilation of plans (arranging schedules, learning plans, instruments for observing student activity sheets, and evaluating instruments in the form of objective tests); Actions, namely the implementation of class actions carried out three times a meeting; Observations which in this case are observations of student activities; Reflection is carried out to assess what has been produced or what has not been completed at the action stage based on the results of the evaluation at the end of the cycle and the observations. The implementation of cycle 2 for the preparation of the plan is based on the results of reflection in cycle 1 . The activities carried out in cycle 2 are intended to improve and enhance learning cycle 1 . However, the researcher determines that research must be carried out at least 2 cycles if cycle 1 has achieved indicators of success while cycle 2 done to reinforce action.

\section{Scenarios for the Application of Problem-Posing Learning Models in Pre-Solution Posing Types}

Actions in building problems and new questions that have the purpose of exploring certain conditions or reformulating problems based on the problems provided are definitions of the problemposing learning model (Silver, 1994). In the study of Hirashima et al. (2008) defines the core in the implementation of problem-posing namely students can make various problems and submit them, some students may repeatedly make the same problem, or make simple problems useful for learning. Furthermore, Suryosubroto (2009) argues that one of the suitable learning models to be able to improve student learning activities is to apply the problem-posing learning model. This learning model can be used to lure students to find the knowledge gained through efforts to find relationships in the information learned, to improve student learning activities in the classroom. 
According to Silver \& Cai (1996) explain that asking independent questions in problem posing can be applied to three cognitive activities namely: Pre-Solution Posing, Within-Solution Posing, and PostSolution Posing. The syntax in applying the problem-posing learning model according to Suyitno (2004) is as follows: explaining the material from the teacher, giving examples of questions, students are asked to send 1 or 2 questions, students complete questions, teachers provide assessments and homework.

Scenarios carried out in this study refer to and adapt from previous theories and research. The scenario of applying the problem-posing learning model with the pre-solution posing type in the basic programming class for the algorithm material and flowchart is shown in Figure 2. Pre-Solution Posing, that is if a student makes a question from the situation that is held. So students are expected to be able to make questions related to questions made previously by the teacher.
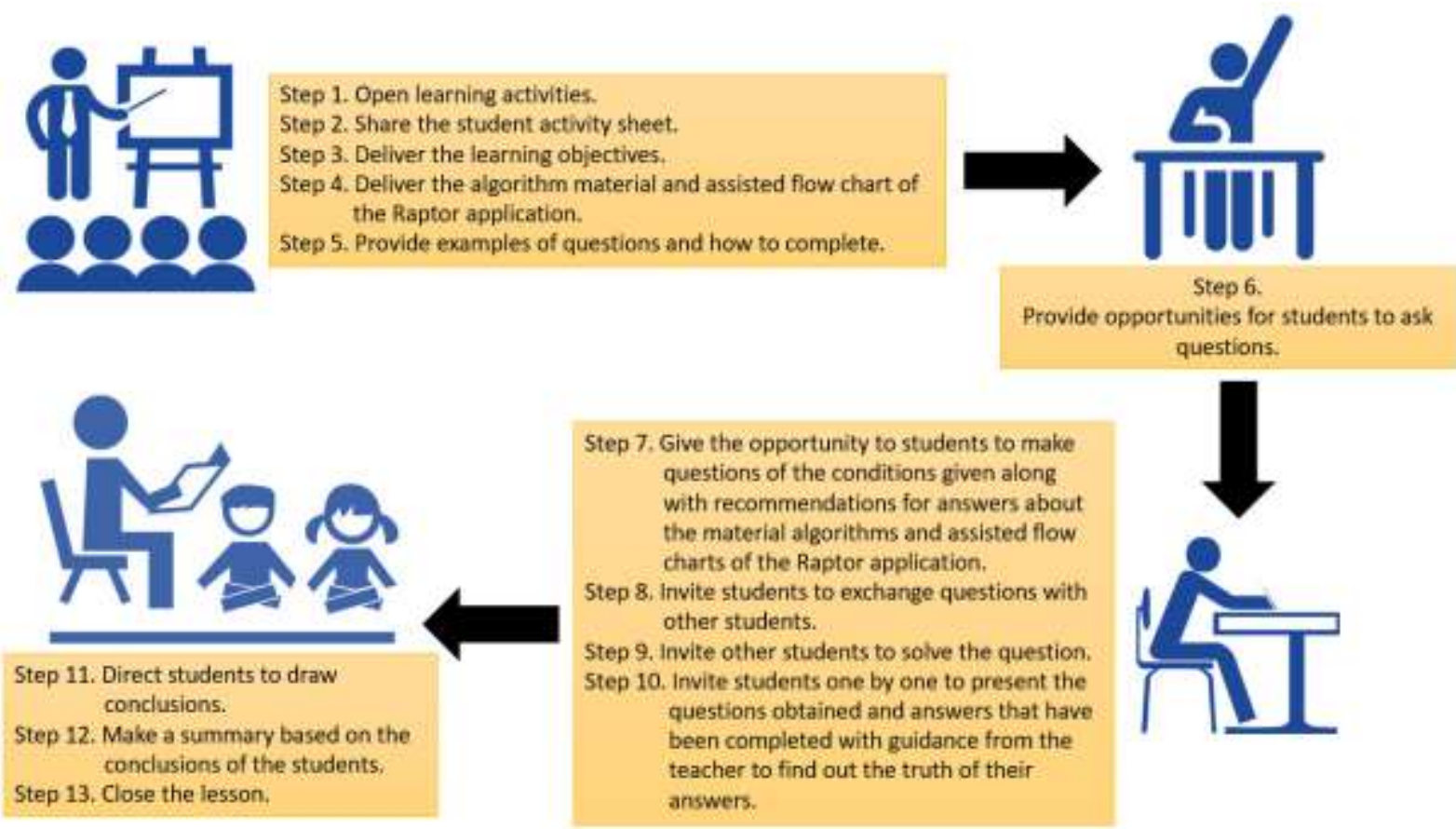

Figure 2. The Problem-Posing Learning Scenario is the Pre-Solution Posing Type

\section{Location and Time of Research}

This research was conducted at the Muhammadiyah 3 Singosari Vocational High School located at Ken Arok Road, Number 9 Singosari, Malang Regency, East Java, Indonesia with learning activities conducted in official classrooms. After conducting the observation process to several schools, the researchers made a selection based on the level of concern faced by the school, especially in the process of learning basic programming. The school which has been chosen as the place for conducting this research is one of the schools of concern and has enough potential problems for researchers to be able to contribute to improving the process of learning basic programming.

\section{Research Subject}

In this study involving subjects namely all tenth graders of multimedia expertise programs totaling 38 students consisting of 26 male students and 12 female students, in the first semester.

\section{Research Protocol}

The rules and ethics in this study adhere to the theory in Hopkins (2008) which states that the rules and ethics in conducting classroom action research consist of 1) Researchers must ensure the integrity and quality of research by designing, reviewing, and doing it; 2) Giving clear direction to the research staff and subjects related to the objectives, methods, and results of the research to be achieved; 3 ) 
Keeping information and respect related to the subject and respondent in the research; 4) Participants in the research can be ascertained not forced, free from anything, and they must be voluntary; 5) Avoiding things that endanger the study participants; 6) Avoiding conflicts of interest/partisanship and having clarity in the independence of conducting research. Beyond these things also implied about the principles of procedure in the commitment to carry out classroom action research such as negotiations in research, rules to become observers, and other things that can affect the performance and results of research.

\section{Type of Action}

If the results obtained do not meet the established success indicators, then the research continues for the next cycle. The cycle will end if the results of the research obtained are appropriate or even exceed the target of the indicators of the success of the research.

\section{Research Instrument}

Some instruments used in data collection are: 1) Student activity observation sheet, which has a function to assess the level of student activity during learning; 2) Objective test sheet with the type of multiple-choice questions that serve to evaluate student learning outcomes carried out at the last meeting of the cycle referred to as the final evaluation cycle.

\section{The indicator of Research Success}

To find out the success of this study, the researchers determined the success indicators as follows:

a. Student activity in a class is said to be achieved when it reaches the final average value with a percentage of $\geq 75 \%$ of students actively involved in the final value of the student activity cycle and classically achieve well qualifications (Adapted from Winarno, 2013).

b. Student learning outcomes in a class are said to be achieved if the individual learning completeness of students with a value of $\geq 70$ (minimum completeness criteria for algorithm and flowchart material on basic programming subjects) and the average grade of classical learning completeness of students with percentages $\geq 75 \%$ of students have completed individually (Adapted from Mulyasa, 2013).

\section{RESULTS AND DISCUSSION}

\section{Learning Process with the Application of Problem-Posing Learning Model in Pre-Solution Posing Type}

For the first cycle of the first meeting with an allocation of 3 x 45 minutes (three hours of study). The learning process takes place namely the teacher opens the learning activity by saying greetings, distributing student worksheets about the algorithm, conveying the learning objectives in the form of basic competencies that must be achieved, conveying concisely and clearly about the application of the problem posing learning model (what should students do?), all students seem to pay attention, after the material is delivered then the teacher gives examples of questions and how to solve, the teacher gives the opportunity to all students to make questions of the conditions given along with recommendations for answers about the algorithm material that must pass the validation first by the teacher shown in Figure 3, the teacher invites students to exchange questions with other students, students who have exchanged questions are instructed to complete the questions, after that the teacher invites students one by one to present the questions obtained and the answers are given has been equipped with guidance from the teacher to find the truth of their answers, then the teacher directs students to draw conclusions from the algorithm material, the teacher makes a summary based on students' conclusions, and closes the lesson for cycle 1 of this first meeting. 


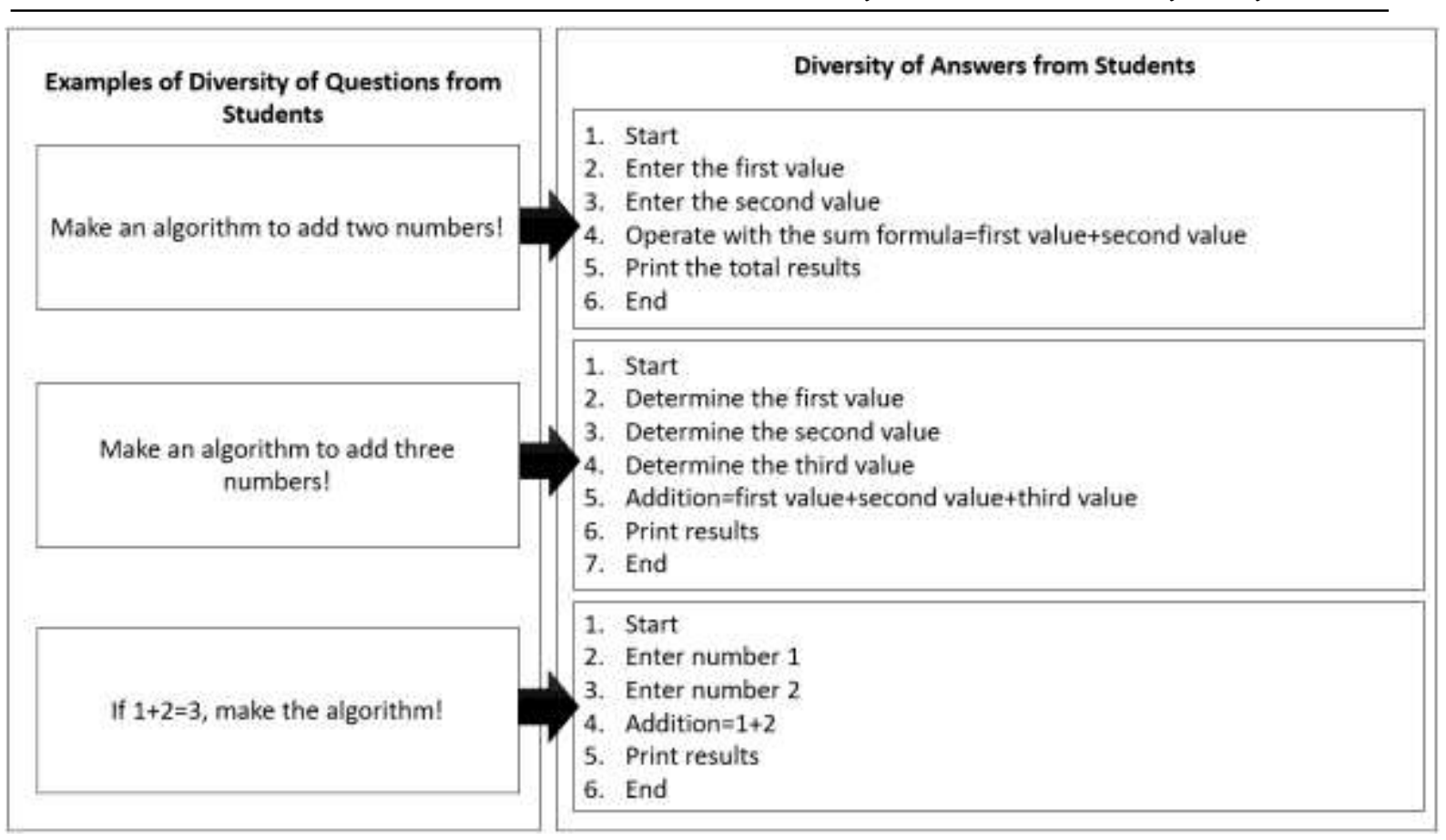

Figure 3. Problem-Posing Activity in the First Cycle of the First Meeting

From the results of the process in the first cycle of the first meeting students tend to still look stiff because they are still adapting to the application of the problem-posing learning model, which they previously learned conventionally, the teacher delivered the material and students were quite attentive if there were practices and assignments. By applying this problem-posing learning model, students feel forced to be active in class, because according to the theory that problem-posing can increase student activity when learning takes place, students must find their knowledge through making questions, even though they are guided by the teacher so as not to out of context.

Based on Figure 3 it can be seen that, students are directed to make questions that have diversity, at first the teacher instructs to make questions and recommendations on answers related to algorithms for addition operations, then generated various forms of questions, they tend to make an average question which is almost the same as before, the difference is the pattern of sentences and the conditions shown by the question, but still have the same purpose. The teacher in the first cycle of the first meeting provides examples of questions that tend to be easier, so students can absorb slowly. The recommendations of their answers also look very varied, some use 7 lines of an algorithm and some use 6 lines, but the goals and results are the same.

For the first cycle of the second meeting the material presented is a flowchart with the Raptor application, students are still constrained to use the Raptor application, then the teacher gives a repetition of practice and material again, after students feel they have understood the material, the teacher gives the opportunity to all students to ask questions about conditions given along with recommendations for answers in the material flow diagram shown in Figure 4. The teacher invites students to exchange questions with other students, students who have exchanged questions are instructed to complete the questions, after which the teacher invites students one by one to present the questions that are obtained and completed answers using the Raptor application with guidance from the teacher to find out the truth of their answers, then conclude the material and close the meeting.

The results obtained from the first cycle of the second meeting are that on average it can be seen that students do not look stiff in learning by applying the problem-posing learning model, they begin to adapt and familiarize conditions that require them to be active in learning, but they have a little difficulty 
when using the Raptor application because it is the first time, where there is still a connection between the previous material, namely the algorithm before making a flowchart using the Raptor application.
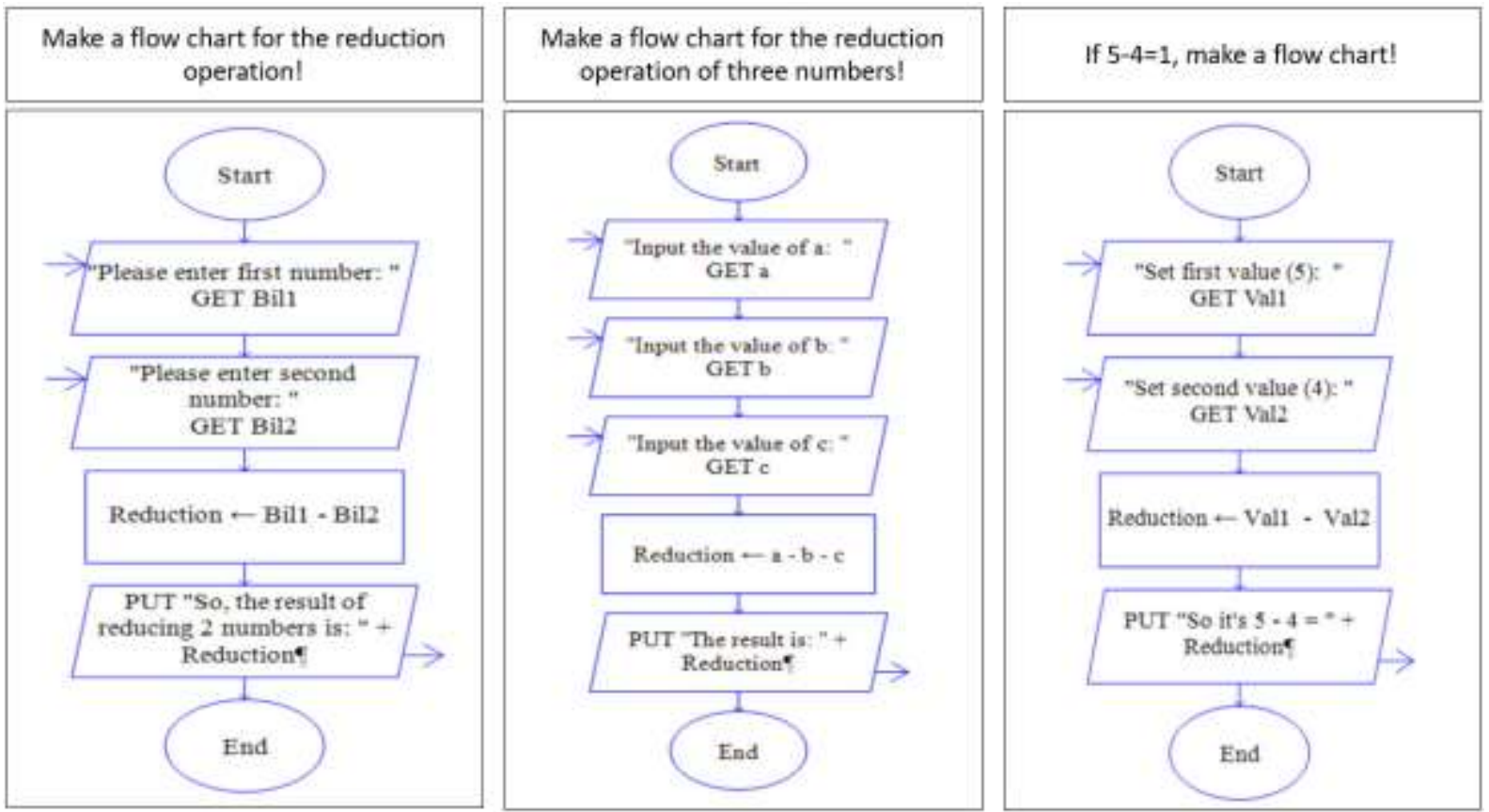

Figure 4. Problem-Posing Activity in First Cycle of the Second Meeting

Seen in Figure 4, the teacher gives the conditions for a flow reduction operation diagram, then students make various types of questions and answer recommendations that are immediately practiced in the Raptor application, they play on the pattern and sentence conditions, but still have the same goal.

Then for the first cycle, the third meeting was evaluated with an allocation of $2 \times 45$ minutes (two hours of study). The final evaluation of cycle 1 aims to determine student learning outcomes. All students were asked questions with an instrument that was made in the form of an objective test with multiple-choice items totalling 25 items, which included algorithmic material and flow diagrams assisted by the Raptor application. All students are prohibited from cheating, they must be independent and must believe in individual abilities. All students tend to look quite serious and thorough when working on problems, running in an orderly, and smooth manner. After the first cycle is completed which consists of three meetings, the next stage is reflection which aims to evaluate the implementation of cycle 1 and improve all related technical matters.

The implementation of the first meeting cycle 2 is almost similar to the first meeting cycle 1 , the difference is in the example of questions that are more complicated than before. This time the teacher is more directing questions for cases of formulas in mathematics and cases in everyday life, such as box formulas, triangle areas, how to make a cake, and so on. The students were very enthusiastic in the first meeting of cycle 2 . Figure 5 is an example of a question made by students along with recommendations for answers that have also been validated by the teacher. 


\begin{tabular}{|c|c|}
\hline \begin{tabular}{|l|} 
Examples of Diversity of Questions from \\
Students \\
centimeters and width $=5$ centimeters, \\
what is the area of a rectangle?
\end{tabular} \\
vectangle! Make an algorithm for the \\
casel
\end{tabular}

Figure 5. Problem-Posing Activity in Second Cycle of the First Meeting

Can be seen in Figure 5, also found students who ask questions that the conditions of the soccer field have similarities with rectangular patterns, their ideas like this must be appreciated because they begin to try to build their knowledge by varying various forms of questions that also have a purpose that same. In the second cycle of the first meeting, indeed all students are more serious and not rigid, they are very trying to make questions and answers, and try to give their best answers if they have done the process of exchanging questions.

The findings obtained from the second cycle of the second meeting are that the application of the problem-posing activities went well because this is the fourth process in applying the learning model, so students also tend to understand the material and activities that must be carried out. Recommended questions and answers are presented in Figure 6.
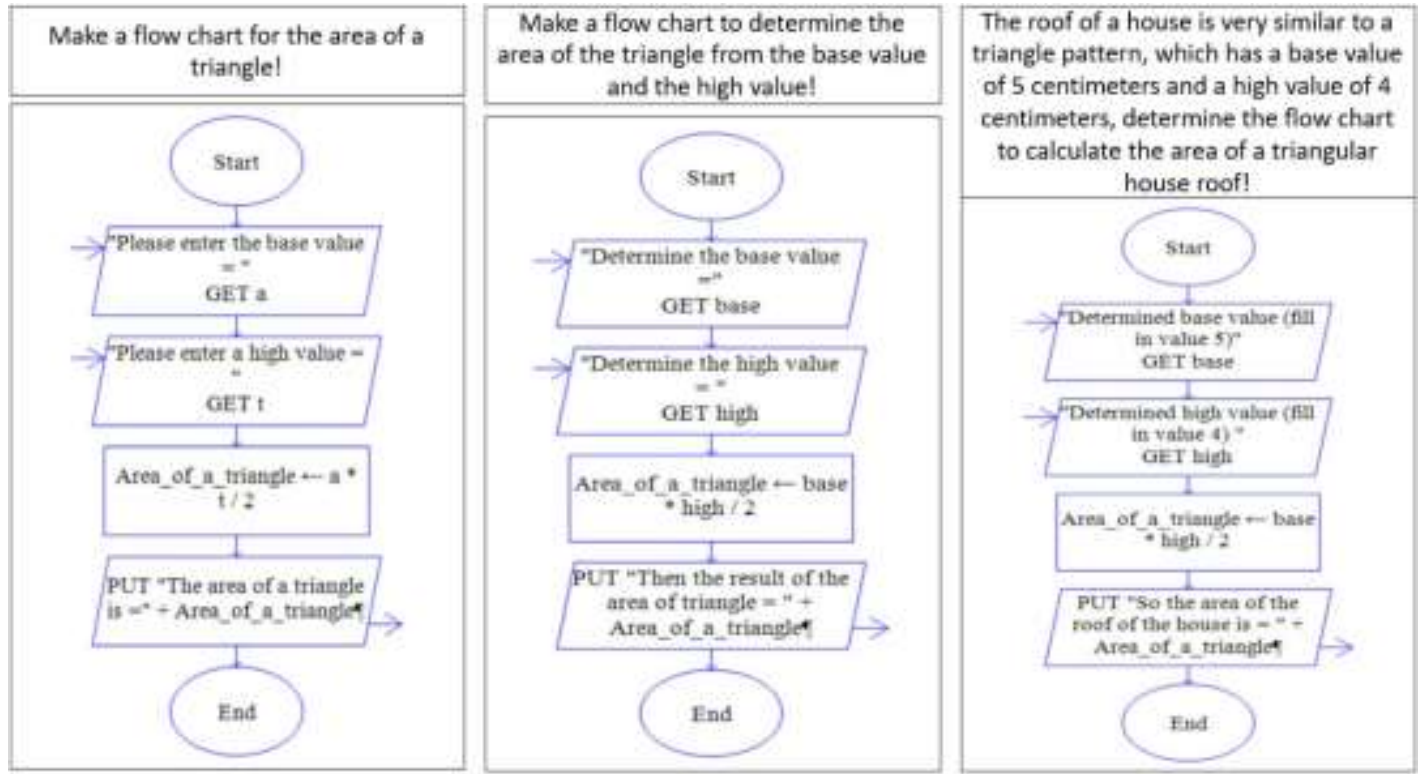

Figure 6. Problem-Posing Activity in Second Cycle of the Second Meeting

Seen in Figure 6, with the same conditions they play on the pattern and condition of the sentence, but still, have the same goal. The findings in the field are that all students no longer have difficulty in operating the Raptor application to create a flowchart, all students tend to look very serious in making 
questions related to circle cases and recommending their answers using the Raptor application. The development of the question form is very unique for each student, drawing several and equating triangular patterns with roof shapes. Various forms of questions are indicators of the implementation of problem-posing that can make students active, develop, and build their knowledge. The final evaluation of cycle 2 is the same as Cycle 1, but the questions asked are different from the questions that have been tested at the end of cycle 1 evaluation.

The implementation of cycle 2 consisting of three meetings has been completed, then a reflection phase is carried out aimed at evaluating the implementation of cycle 2 and knowing the achievement of all related technical matters, especially in terms of implementing problem-posing implementation. It was found that the application of problem-posing began to be understood and students had applied it smoothly according to syntax. Algorithms and flow diagrams also tend to be understood by students, because of the repetition of the material for the second time in cycle 2. Furthermore, in terms of the final results of the activities and learning outcomes are also good. Based on the results obtained, the values and conditions have met the indicators of research success, therefore the implementation of this preliminary study stops at cycle 2 .

\section{Student Activities}

To obtain student activity data in this study used non-test type observation instruments with the instrument used was the observation sheet. Observations were made by two observers, each of whom was assigned to observe 19 students. Observations were made to obtain a general picture of student activities from the beginning to the end of the learning process, according to the steps in the problemposing learning model.

The indicators of the student activity observation sheet in this study adjust to the steps in applying the problem-posing learning model and adapting to Paul B. Diedrich's theory in Sardiman (2014) which classifies student activities, namely: visual, oral, listening, writing, drawing, motor, mental, and emotional.

To determine the qualifications of activities in this observation, according to Kunandar (2013), it was done by using a range of scores from 0 to 1 , namely for the activities of students who were given "yes" with a score of 1 and for activities that were not "no" with a score of 0 . As for the steps to process the results of student activities observed, namely as follows:

1. Give a score for each aspect observed.

2. Add the acquisition score.

3. Entering the acquisition score into the calculation of student activities is done by the following formula:

$$
\text { Total Score }=\frac{\text { Acquisition Score }}{\text { Maximum Score }} \boldsymbol{x} 100 \%
$$

4. Providing information on student activity scores is presented in Table 1.

Table 1. Description of Student Activity Score

\begin{tabular}{cc}
\hline Student Activity Score & Qualification \\
\hline $91 \%-100 \%$ & Very Good \\
$71 \%-90 \%$ & Well \\
$61 \%-70 \%$ & Enough \\
$0 \%-60 \%$ & Less
\end{tabular}

Source: Adapted from Riduwan \& Akdon (2013) 
The assessment of student activities was carried out by two observers, who observed all conditions based on the statement on the observation sheet totaling 16 items. The details of the 16 statements are presented in Table 2.

Table 2. Statements in Observing Student Activities

\begin{tabular}{|c|c|c|}
\hline No. & Activity Indicator & Statements \\
\hline 1 & Visual Activities & $\begin{array}{l}\text { Students pay attention to the teacher when describing the material of the } \\
\text { algorithm and flowchart }\end{array}$ \\
\hline 2 & Visual Activities & $\begin{array}{l}\text { Students pay attention to the teacher when giving examples of questions in the } \\
\text { form of problems in the daily environment relating to the material of the } \\
\text { algorithm and flowchart }\end{array}$ \\
\hline 3 & Visual Activities & Students pay attention to the teacher when completing sample questions \\
\hline 4 & Listening Activities & $\begin{array}{l}\text { Students listen to the descriptions conveyed by the teacher during the learning } \\
\text { process }\end{array}$ \\
\hline 5 & Listening Activities & Students discuss with teachers about material that is not yet understood \\
\hline 6 & Oral Activities & $\begin{array}{l}\text { Students ask questions to the teacher after the teacher presents the material } \\
\text { description }\end{array}$ \\
\hline 7 & Oral Activities & Active students ask questions in learning \\
\hline 8 & Motor Activities & Active students conduct experiments to make question recommendations \\
\hline 9 & Motor Activities & Active students conduct experiments to make recommendations for answers \\
\hline 10 & Writing Activities & Active students make recommendations for questions \\
\hline 11 & Writing Activities & Active students make recommendations for answers \\
\hline 12 & Mental Activities & $\begin{array}{l}\text { Students actively solve questions given by other students correctly and } \\
\text { precisely }\end{array}$ \\
\hline 13 & Mental Activities & Active students present questions that have been obtained along with answers \\
\hline 14 & Emotional Activities & $\begin{array}{l}\text { Students are interested and eager to follow basic programming learning by } \\
\text { applying the problem-posing learning model }\end{array}$ \\
\hline 15 & Emotional Activities & $\begin{array}{l}\text { Students dare to express opinions to other students about the questions they } \\
\text { have completed }\end{array}$ \\
\hline 16 & Emotional Activities & Students dare to conclude the material they have learned \\
\hline
\end{tabular}

Based on observations made, can be known that the average student activity in the first cycle of the first meeting was $70.88 \%$ with sufficient qualifications. In the first cycle, the second meeting increased to $73.13 \%$ with good qualifications. So, by looking at the average activity of students in cycle 1 , it can be concluded that the activity is at a percentage of $72.00 \%$ with good qualifications. The achievements of student activities in cycle 1 have not yet been fulfilled. There are still a few statements of student activity that are dominated by enough categories. This tends to be caused by students who feel unfamiliar with the application of problem-posing learning models that require students to be active in the learning process, students still do not understand the material, students tend not to understand the questions and recommendations expected, students still tend not to express their opinions in conclude the material being studied. However, in the first cycle of the first and second meeting the most striking is the value of the statement that students are interested and eager to follow basic programming learning by applying the problem-posing learning model, with the findings we assume that they may only feel the application of learning models that require students to follow all the rules in the syntax of the problem-posing learning model, even though they feel this arrangement has a good impact because it can make students active in class and also learn to be organized and orderly. The findings from cycle 1 are used for the process of reflection in the application of action in cycle 2 . The results of comparison of observations of student activities that have been carried out in both cycles are shown in Figure 7. 


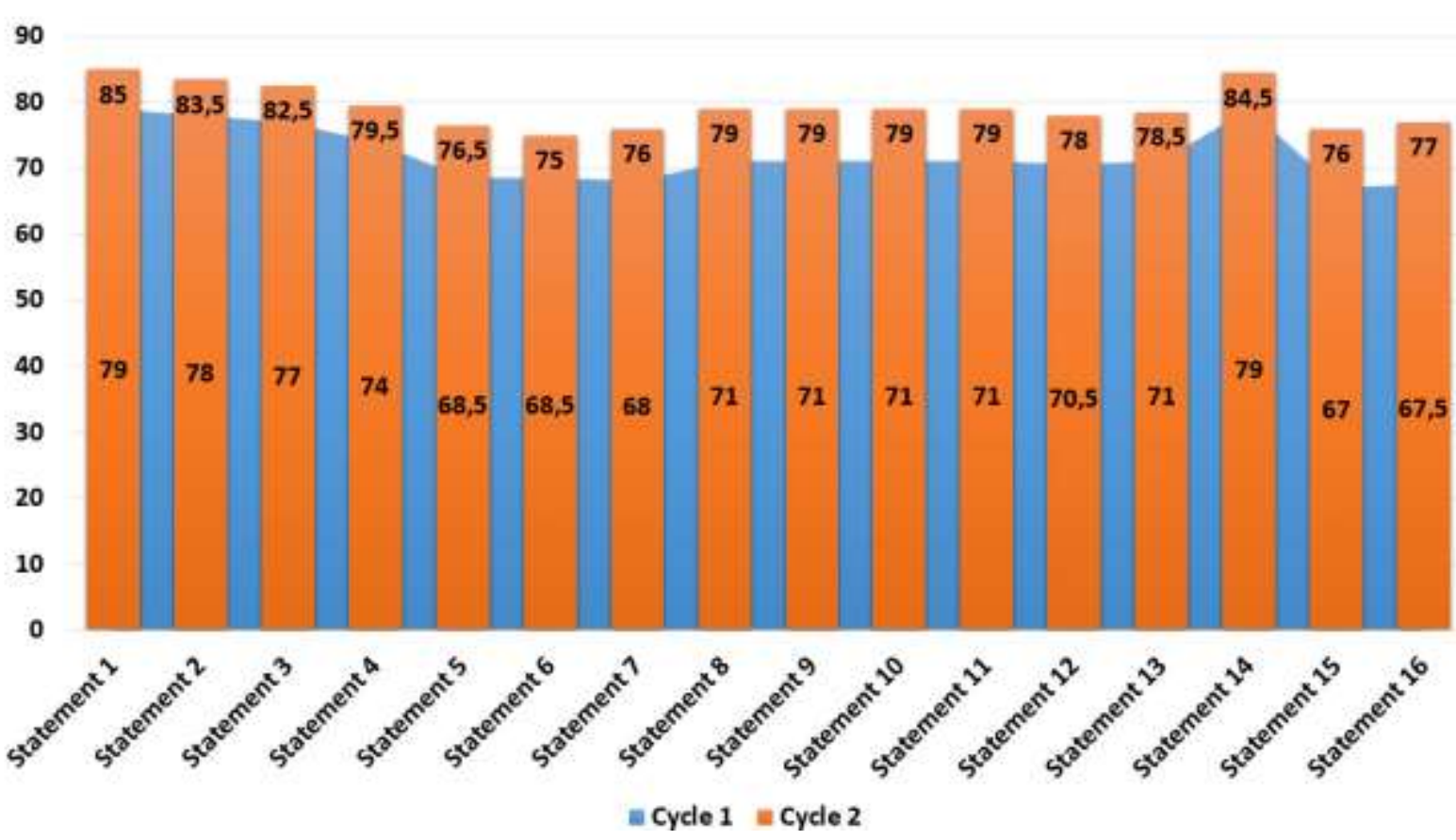

Figure 7. Comparison of the Results of the Average Student Activity Between the First Cycle and Second Cycle

The average activity of students in the second cycle of the first meeting was $76.94 \%$ with good qualifications. In cycle 2 the second meeting increased to an average value of student activities, namely $81.56 \%$ with good qualifications. Then the average activity value of students in cycle 2 obtained a percentage of $79.25 \%$ with good qualifications. Compared to the value obtained in the first cycle the first meeting rose $6.06 \%$, the second meeting rose $8.43 \%$, and the average value rose $7.25 \%$. This shows an increase in each statement between the acquisition of cycle 1 and cycle 2 (see Figure 7). Progress is seen in statement number 8-13 which is the main indicator of the syntax of the problem-posing learning model. Most likely is that students tend to understand what must be done when learning basic programming by applying the problem-posing learning model. Achievement results obtained from cycle 2 activities have met the indicators of success. The increase in student activity occurs as a whole due to the adaptation of students in applying the problem-posing learning model, from the 4 times face-to-face meetings that have been conducted, very clear it is seen that students process to understand the rules or things that are done in basic programming learning by applying this problem-posing learning model.

\section{Student Learning Outcomes}

In Arifin (2014) stated that the method of scoring objective tests in the form of multiple-choice questions there are three types, namely as follows: scoring without correction of answers, scoring is an answer correction, and scoring with different weight items.

In this study took the form of scoring without correction of answers, namely scoring by way of each item answered correctly received a value of one (depending on the weight of the item). Student scores are obtained by calculating the number of items answered correctly, and there is no reduction in the score if the answer is wrong. Using the following formula:

$$
S=\frac{B}{N} x 100
$$

With a value scale of $0-100$

Information:

$\mathrm{S}=$ Score of students given

$\mathrm{B}=$ Number of correct student answers

$\mathrm{N}=$ Number of all questions 
Student learning outcomes are obtained based on the results of the final evaluation conducted at every third meeting in each cycle. In the Depdiknas (2004) states that mastery learning is the achievement of learning outcomes for the level of mastery of competence.

Achievement of learning outcomes in cycle 1 states that 21 students achieved complete predicate with a percentage of completeness $55.26 \%$, while students who achieved incomplete predicate with a percentage of $44.74 \%$ were 17 students. It was also found that the results obtained by students from the final evaluation of cycle 1 with a minimum score of 52 and the maximum value were 88 . After the final evaluation of the first cycle was carried out then a reflection for learning outcomes was carried out, after reviewing the results obtained still did not meet the research success indicators because the student's mastery score has not reached $\geq 70$ and the average grade of students' classical learning completeness has not reached a percentage of this $75 \%$.

Achievement of learning outcomes for cycle 2 which experienced a significant increase compared to the results of the final evaluation of learning outcomes in the previous cycle. The result is that 29 students achieved complete predicate with a percentage of completeness of $76.23 \%$, while students who achieved incomplete predicate with a percentage of $23.68 \%$ were 9 students. The results obtained by students from the final evaluation of cycle 2 with the achievement of a minimum score of 52 and the maximum value is 96 . The increase in student learning outcomes is an impact of student activity which also increases. Reflections from the results of the final cycle 2 evaluation are stated to have met the research success indicators for student learning outcomes.

As for the comparison of the average value of student learning outcomes between cycle 1 and cycle 2 is shown in Figure 8, where for cycle 1 the average value is 69.68 with incomplete predicate while for cycle 2 the average value is 76.53 with the complete predicate. The increase that occurs for the average value of student mastery learning is 6.85 points. For completeness of individual learning on learning outcomes in cycle 2 has succeeded in meeting the success indicators set out in this study.

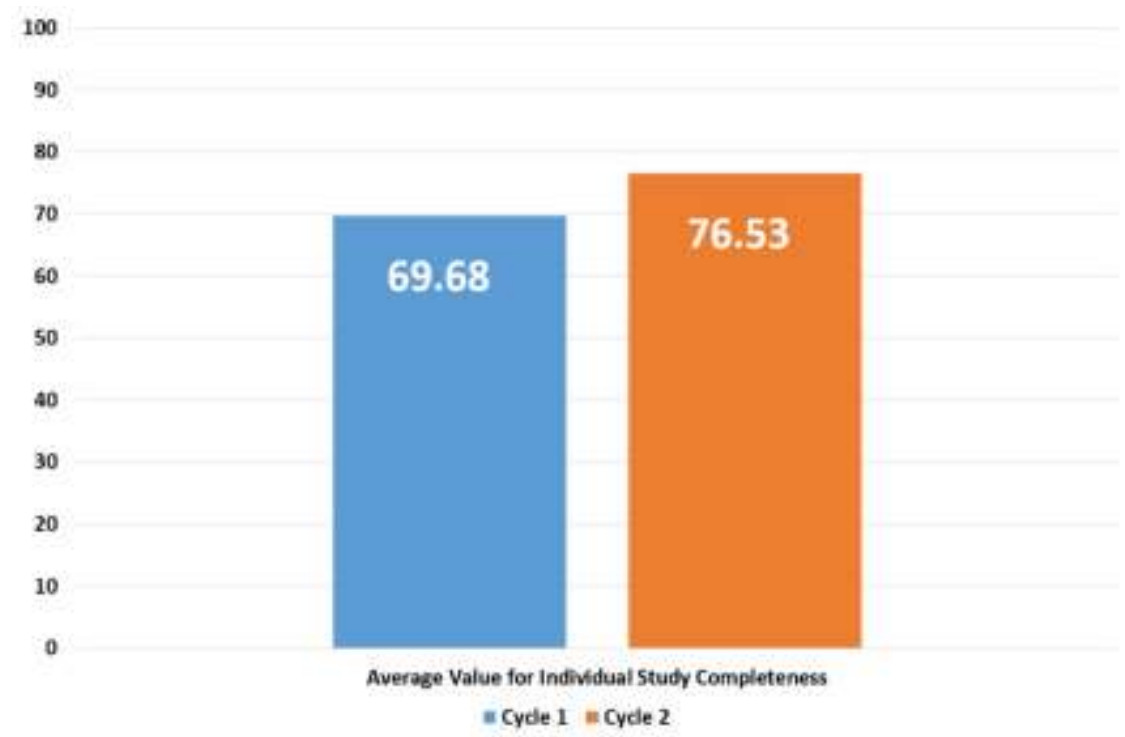

Figure 8. Comparison of the Average Value of Student Learning Outcomes Between the First Cycle and the Second Cycle

Next is the comparison of the average grade of classical learning completeness of students between cycle 1 and cycle 2, for cycle 1 the average value is obtained with a percentage of $55.26 \%$ while for cycle 2 the average value is obtained with a percentage of $76.32 \%$. The increase occurred for the average grade of classical learning completeness of students with an increasing percentage of $21.06 \%$. For classical learning completeness in learning outcomes cycle 2 has succeeded in meeting the success indicators set out in this study. 
Based on the results of observations of activities and learning outcomes of students who have applied the problem-posing learning model in the basic programming class, the final results obtained in cycle 2 tend to be better than the cycle 1. Learning by applying the problem-posing learning model is very active for students to interact and high curiosity, besides that the acquisition of student learning outcomes also tends to be very good. In line with research that is relevant to the research conducted now, namely from Fatoni, Irianto, \& Prasetya (2013) who carry out classroom action research by applying problem-posing learning models combined with think-pair-square models in web design programming classes at secondary schools vocational, the result is an increase in student activity during the implementation of cycle 2, the students showed very actively and enthusiastic. Then student learning outcomes also improved during the implementation of cycle 2 with $90 \%$ of students completing classically.

Then from Purnamawati, Nur, \& Nuridayanti (2017) where this study applies a problem-posing learning model in vocational high schools in electrical engineering classes with the result that there is a very good change and improvement when the learning process by applying the problem-posing learning model especially in practical classes compared to conventional learning. Problem-posing can also increase students' critical thinking skills and their freedom to make things/submit things they know.

Finally by Aryani (2018) who applied a problem-posing learning model on algorithmic and programming material, where the interaction carried out was the availability of questions containing real-life stories, algorithms containing program structure, answers or solutions containing the level of program execution, the context of the questions, the type of question (filling in program code snippets or compiling program code snippets) and containing the cognitive domain level in bloom taxonomy. The results obtained from this study are excellent student activities and also very good student learning outcomes. Especially for the problem-posing itself is very suitable when applied to the case of programming and the combination with critical thinking models. Some researchers have explained the results of their research and agreed that the problem-posing learning model is very suitable to be applied in vocational high schools, more specifically for programming classes. The results of the effects of applying the problem-posing learning model compared to conventional models have also been reported with a very good increase in student activity and learning outcomes.

After determining the good effect of applying the problem-posing learning model in the basic programming class, the results of this study will be further utilized to design and build systems/applications that will automatically embed the syntax of the problem-posing learning model in the flow of interaction automatically with artificial intelligence in the realm of integrated educational media technology.

\section{CONCLUSION AND FUTURE WORK}

In this paper, a preliminary study with classroom action research in applying the problem-posing learning model of the pre-solution posing type to the algorithmic material and assisted flowchart of the Raptor application for basic programming classes in the tenth grade of vocational high school has been carried out. This study concludes that by applying the proposed model it is known the results of student activities for cycle 1 with a percentage of $72.00 \%$ well quality and for cycle 2 there is an increase of $79.25 \%$ with well quality, then for achievement in student learning outcomes in cycle 1 with the percentage of classical completeness which is $55.26 \%$ with an average value of individual learning completeness of 69.68 and in cycle 2 it has increased for the average value of individual learning completeness which is 76.53 , for the percentage of classical completeness of $76.32 \%$, success in this study we will have an impact on the preliminary study that we conducted, so we have gotten a picture to develop applications/systems/interactive media/games that will support operations in applying the problem-posing learning model automatically in the upcoming basic programming class. 
Future work for this research can produce applications/systems/interactive media/games that automatically apply the syntax of problem-posing learning models in the flow of interaction that will be implemented in basic programming learning as one of the innovations in learning media.

\section{REFERENCES}

Arifin, Z. (2014). Evaluasi Pembelajaran. Bandung: PT. Remaja Rosdakarya.

Arikunto, S. (2014). Prosedur Penelitian Suatu Pendekatan Praktik. Jakarta: PT. Rineka Cipta.

Aryani. (2018). Multimedia Pembelajaran untuk Algoritma dan Pemrograman menggunakan Model Pembelajaran Problem-Posing untuk Menunjang Critical Thinking. Bandung: Skripsi Universitas Pendidikan Indonesia.

Daungcharone, K., Panjaburee, P., \& Thongkoo, K. (2017). Using Digital Game as Compiler to Motivate C Programming Language Learning in Higher Education. IEEE IIAI-AAI, (pp. 533-538).

Debabi, W., \& Champagnat, R. (2017). Towards Architecture for Pedagogical and Game Scenarios Adaptation in Serious Games. International Conference E-Learning, (pp. 63-70).

Depdiknas. (2004). Penelitian Pembelajaran Pengetahuan Sosial. Depdiknas Derjen Dikdasnas.Dit PLP Materi Pelatihan Terintergrasi Buku 2. Jakarta: DEPDIKNAS.

Dwinanto, A. (2017). Pengembangan dan Analisis Kualitas Game Edukasi Menggunakan Metode Pembelajaran Kooperatif Tipe TGT pada Materi Pemrograman Dasar Siswa SMK Kelas X. Yogyakarta: Thesis of UNY.

Fatoni, I. M., Irianto, W. S. G., \& Prasetya, D. D. (2013). Penerapan Metode Pembelajaran Problem-Posing dalam Metode Pembelajaran Think-Pair-Square (PP-TPS) untuk Meningkatkan Keaktifan Siswa dan Hasil Belajar Siswa pada Mata Pelajaran Desain WEB di Kelas X TKJ SMK Muhammadiyah 1 Mojokerto. Malang: Skripsi Pendidikan Teknik Informatika Universitas Negeri Malang.

Hirashima, T., Yokoyama, T., Okamoto, M., \& Takeuchi, A. (2008). An Experimental Use of Learning Environment for Problem-Posing as Sentence-Integration in Arithmetical Word Problems. International Conference on Intelligent Tutoring Systems, (pp. 687-689).

Hong, T. \& Chu, HC. (2017). Effects of a Situated 3D Computational Problem-Solving and Programming GameBased Learning Model on Students' Learning Perception and Cognitive Loads. IEEE IIAI-AAI, (pp. 596$600)$.

Hopkins, D. (2008). The $4^{\text {th }}$ Edition - A Teacher's Guide to Classroom Research. England: Open University Press and McGraw-Hill Education.

Hsu, W. C., \& Lin, H. C. K. (2017). Impact of Applying WebGL Technology to Develop a Web Digital GameBased Learning System for Computer Programming Course in Flipped Classroom. EITT, (pp. 64-69).

KEMDIKBUD RI. (2018). Struktur Kurikulum SMK Perdirjen Nomor 07 Tahun 2018. Jakarta: Kementerian Pendidikan dan Kebudayaan Republik Indonesia, Direktorat Jenderal Pendidikan Dasar dan Menengah.

Kiss, G., \& Arki, Z. (2017). The influence of game-based programming education on the algorithmic thinking. Procedia - Social and Behavioral Sciences, June 2016, (pp. 613-617).

Kunandar. (2013). Penilaian Autentik (Penilaian Hasil Belajar Peserta Didik Berdasarkan Kurikulum 2013) Suatu Pendekatan Praktis Disertai dengan Contoh. Jakarta: PT. RajaGrafindo Persada.

Kunimune, H., \& Niimura, M. (2014). Preliminary Evaluation of a Problem-Posing Method in Programming Classes. Procedia Computer Science, (pp. 794-802).

Kunkle, W. M. \& Allen, R. B. (2016). The Impact of Different Teaching Approaches and Languages on Student Learning of Introductory Programming Concepts. ProQuest Dissertations and Theses.

Likmalatri, L. (2018). Pemrograman Dasar untuk SMK/MAK Kelas X Semester 1 dan 2 Bidang Keahlian Teknologi Informasi dan Komunikasi. Surakarta: Putra Nugraha.

Malliarakis, C., Satratzemi, M., \& Xinogalos, S. (2014). Designing educational games for computer programming: A holistic framework. Electronic Journal of E-Learning, 12(3), 281-298.

Mulyasa. (2013). Pengembangan dan Implementasi Kurikulum 2013. Bandung: PT Remaja Rosdakarya.

Purnamawati, Nur, H., \& Nuridayanti. (2017). Application Of Problem-Posing Learning Model On Electrical Engineering Subject in SMK 2 Makassar, International Conference ADRI-5, (pp. 4-11).

Riduwan \& Akdon (2013). Rumus dan Data Dalam Analisis Statistika. Bandung: Alfabeta.

Rozali, N. F. \& Zaid, N. M. (2017). Code Puzzle: ActionScript 2.0 Learning Application Based on Problem Based Learning Approach, IEEE ICT ISPC, (pp. 2-5).

Sardiman, A. M. (2014). Interaksi dan Motivasi Belajar Mengajar. Jakarta: PT. Raja Grafindo Persada.

Silver, E. A. (1994). On mathematical problem-posing. For the Learning of Mathematics. JSTOR Journal, 14(1), $19-28$. 
Silver, E. A., \& Cai, J. (1996). An Analysis of Arithmetic Problem-posing by Middle School Students. Journal of Research in Mathematics Education, 27(5), 521-539.

Soloway, E., \& Spohrer, J. (1989). Studying the novice programmer in $1^{\text {st }}$ ed. Hillsdale: L. Erlbaum.

Stigall, J., Sharma, S., \& Member, S. (2017). Virtual Reality Instructional Modules for Introductory Programming Courses. IEEE ISEC, (pp. 34-42).

Supianto, A. A., \& Hafis, M. (2018). GTRAS: Graphical Tracking Activity System for Problem-Posing Learning Process Insights. ICACSIS, (pp. 231-235).

Supianto, A. A., Hayashi Y., \& Hirashima, T. (2017). Designing Scaffolding System in a Problem-Posing Learning Environment. ICSITech, (pp. 546-551).

Supianto, A. A., Hayashi, Y., \& Hirashima, T. (2016). Analysis of Steps in Posing Arithmetic Word Problem as Sentence-Integration on Interactive Learning Environment. ICCE, 1(11), (pp. 242-251).

Suryosubroto. (2009). Proses Belajar Mengajar di Sekolah Wawasan Baru, Beberapa Metode Pendukung, dan Beberapa Komponen Layanan Khusus. Jakarta: Rineka Cipta.

Suyitno, A. (2004). Dasar-Dasar dan Proses Pembelajaran Matematika I. Semarang: Universitas Negeri Semarang.

Syahidi, A. A., Asyikin, A. N., \& Asy’ari. (2018). Applying Student Team Achievement Divisions (STAD) Model on Material of Basic Programme Branch Control Structure to Increase Activity and Student Result. ICVEE - IOP Conference Series: Materials Science and Engineering, 336(1), (pp. 1-8).

Topalli, D., \& Cagiltay, N. E. (2018). Improving Programming Skills in Engineering Education through ProblemBased Game Projects with Scratch. Computers and Education, (pp. 64-74).

Winarno. (2013). Pembelajaran Pendidikan Kewarganegaraan. Jakarta: Bumi Aksara.

Yang, T.-C., Hwang, G.-J., Yang, S. J. H., \& Hwang, G.-H. (2015). A Two-Tier Test-based Approach to Improving Students' Computer-Programming Skills in a Web-Based Learning Environment. Journal of Educational Technology \& Society, 18 (November), 198-210. 